\title{
HERITABILITIES OF BODY SIZE BY GROWTH HORMONE (GH-Msp1) GENOTYPES USING PCR-RFLP IN ONGOLE GRADE CATTLE
}

\author{
U. Paputungan ${ }^{1}$, L. Hakim ${ }^{2}$, G. Ciptadi ${ }^{2}$ and H. F. N. Lapian ${ }^{1}$ \\ ${ }^{1}$ Faculty of Animal Sciences, Sam Ratulangi University, \\ Jl. Kampus Unsrat Bahu, 95115, Manado - Indonesia \\ ${ }^{2}$ Faculty of Animal Husbandry, Brawijaya University, \\ Jl. Kampus Fapet UB, 65145, Malang -Indonesia \\ CorrespondingEmail: umarfapet@yahoo.com
}

Received June 27, 2015; Accepted August 16, 2015

\begin{abstract}
ABSTRAK
Tampilan genetik dalam istilah heritabilitas yang merupakan faktor penting pada sifat ekonomis ternak untuk pewarisan ukuran tubuh belum sepenuhnya dikaji pada ternak sapi Peranakan Ongole (PO). Tujuan penelitian ini adalah menentukan nilai-nilai heritabilitas bobot badan, lingkar dada dan panjang badan pada sapi PO. Total 37 sampel darah diambil dari tetua induk betina dan 2 sampel darah dari tetua pejantan sapi Ongole. Semua sampel darah diuji gambaran keberadaan genotipe lokus hormon pertumbuhan $(\mathrm{GH})$ menggunakan metode PCR-RFLP yang melibatkan enzim Msp1 pada "agarose-gel" $(1,2 \%)$ melalui elektroforesis. Data dianalisis menggunakan program stastistik dalam Excel XP. Hasil analisis memperlihatkan bahwa rata-rata estimasi fenotipe populasi sapi PO untuk bobot hidup, lingkar dada dan panjang badan masing-masing adalah 445,41 $\pm 45,95 \mathrm{~kg} ; 175,35 \pm 4,11 \mathrm{~cm}$ dan 139,70 \pm $5,73 \mathrm{~cm}$. Nilai dugaan heritabilitas bobot badan, lingkar dada dan panjang badan masing-masing adalah 0,$24 ; 0,003$ and 0,41. Nilai heritabilitas ternak untuk bobot badan dan panjang badan dapat dikategorikan ke dalam nilai tampilan genetik sedang (moderate) sampai tinggi (high), sedangkan nilai heritabilitas lingkar dada dapat dimasukkan dalam kategori haritabilitas rendah (low) untuk sifat ekonomis ternak.
\end{abstract}

Kata Kunci: Enzim GH-Msp1, sapi Peranakan Ongole, sifat genotipe, ukuran tubuh

\begin{abstract}
Genotypic performance in term of heritability as the crucial factor of animal economical traits for body size inheritance had not been fully studied in Ongole-grade cattle. The objectives of this research were to define the heritability values of live weight, chest girth and body length in Ongole-crossbred cattle. Total of 37 blood samples were collected from parental cows and 2 blood samples from parental Ongole breed bulls. All blood samples were screened for the presence of growth hormone $(G H)$ locus using PCR-RFLP method involving restricted enzyme Mspl on agarose-gel (1.2\%). Data were analyzed using statistical program in Excel XP. Results showed that the phenotypic estimation average of Ongole grade cattle population of live weight, chest girth and body length were $445.41 \pm 45.95 \mathrm{~kg}, 175.35 \pm$ $4.11 \mathrm{~cm}$, and $139.70 \pm 5.73 \mathrm{~cm}$, respectively. The heritability values of animal live weight, chest girth and body length in this study were $0.24,0.003$, and 0.41 , respectively. These heritability values of animal live weight and body length would be categorized as moderate to high genotypic performance values, while the heritability of animal chest girth was included in low heritability standard of the animal economical trait performance.
\end{abstract}

Keywords: GH-Msp1 enzyme, Ongole-grade cattle, genotypic traits, body size 


\section{INTRODUCTION}

The difference in the phenotypes of animals in the single locus-example is a function of the genotypic value. Parents do not pass their genotype on to their progeny but rather pass on only a random sample of one gene to each locus of the progeny. The goal of animal breeders is rapid genetic improvement, for which accurate prediction of breeding value is the most crucial factor. The breeder can rank the animals and cull those with the poorest evaluations while selecting those with the best evaluation as replacements. Accurate evaluation requires proper application of heritability and relationships to records of the either animal weight, chest girt or body length and its relatives (Van Vleck et al., 1987).

In animal industry, growth traits of animals are always of primary concern during breeding for its determinant economical value. With the development of molecular biology and biotechnology, scientists are able to achieve more accurate and efficient selection goal by markerassisted selection (MAS). In general, validating the genetic markers of growth traits is the initial and crucial step to establish a MAS system (Allan et al., 2007).

Growth hormone $(\mathrm{GH})$ is an anabolic hormone synthesized and secreted by the somatotroph cells of the anterior lobe of the pituitary in a circadian and pulsatile manner, the pattern of which plays an important role in pubertal, prenatal and postnatal longitudinal growth and development, tissue growth, lactation, reproduction, as well as protein, lipid and carbohydrate metabolism (Ayuk and Sheppard, 2006). Effects of GH on growth were observed in several tissues, including bone, muscle and adipose tissue, so that $\mathrm{GH}$ gene, with its functional and positional potential, has been widely used for marker in several livestock species, including the cattle such as Bos taurus and Bos indicus (Beauchemin et al., 2006). It has been reported that the restriction fragment length polymorphisms (RFLP) of GH were associated with body weight in Grati dairy cows (Maylinda, 2011).

The studies of GH gene MspI locus have been reported in Ongole grade cattle (Sutarno et al., 2005), Brahman cattle (Beauchemin et al., 2006), Indian Zebu cattle (Shodi et al., 2007) and West coastal Sumatera cattle (Jakaria et al., 2007; Jakaria et al., 2009). Their studies indicated that $\mathrm{MspI}^{+/+}$and $\mathrm{MspI}^{+/-}$genotypes can be used as the candidate genes in cattle selection for breeding program. The genotypic value is defined as the deviation of the phenotype from the average of the two homozygous phenotypes (Jain and Prabhakaran, 1992).

The difference between breeding values is additive gene and represent the term of heritability for certain animal economical trait such as animal live weight, chest girth and body length. Heritability $\left(\mathrm{h}^{2}\right)$ is defined as the ratio of the additive genetic variance to the phenotypic variance. Thus, $\mathrm{h}^{2}$ is the proportion of the total variance that is due to differences among the breeding values of individuals in the population (Van Vleck et al.,1987). However, the heritability of body size represented by body weight, chest girth and body length in individual Ongole grade cow, referred to its additive genetic merit of body size, has not been much studied. The objectives of this research were to define the genotypic performance referring to heritability of live weight, chest girth and body length from genotypic frequency of growth hormone $(\mathrm{GH})$ $M s p I$ enzyme-restriction in Ongole grade cows population in North Sulawesi province of Indonesia.

\section{MATERIALS AND METHODS}

This study was carried out in the Northern Sulawesi Island of Indonesia using 37 cows (age ranging 4 to 5 years old) of Ongole grade cattle at Tumaratas Village as the artificial insemination (AI) service center of Minahasa regency, North Sulawesi province of Indonesia. All parental cows (G0) were reared under private areas belong to farmers with unknown ancestors. Progenies (G1) were born from those G0 mated by artificial insemination using germ plasmas (semen) of the two Ongole bulls called "Kirsta" and "Tunggul" from "The Artificial Insemination Bull Germ Plasma Center" in Singosari, East Java Province, Indonesia.

Prior to blood collection, body weights of animals (G0 and G1) were determined by using a digital weighing scale when animals were standing as described in (Ozkaya and Bozkurt, 2008). The total of $37 \mathrm{G} 0$ consisted of 20 superior body weight animals (cow weights heavier than at least one fifth standard deviation above the mean) and 17 inferior body weight animals (cow weights lighter than one and half standard deviation below the mean) among cow (G0) population ( $\mathrm{n}=363$ heads, with body weight average of $440.20 \pm$ 
$58.03 \mathrm{~kg}$ ) were included in this study as described in (Paputungan et al., 2000).

The genotyping process was conducted at the Biotechnology Laboratory, Department of Biological Science, Faculty of Mathematics and Natural Science, Sam Ratulangi University, Manado. Genomic DNA from whole blood of Ongole grade cows, bulls and their calves were purified by standard protocol using proteinase $\mathrm{K}$ digestion as described by DNA extraction kit (AxyPrep Blood Genomic DNA Miniprep kit, AXYGEN Biosciences, Union city, CA, 94587, USA).

Following the genomic DNA isolation, the animals were genotyped for GH locus using PCRRFLP (Polymerase chain reaction-restriction fragment length polymorphism) and $1.2 \%$ agarose gel electrophoresis (Sulandari and Zein, 2003). Amplification of the fragment of $327 \mathrm{bp}$ at intron 3 (Gordon et al., 1983) was done with PCR using the forward primer of 5'CCCACGGGCAAGAATGAGGC-3'; and reverse primer of 5'-TGAGGAACTGCAGGGGCCCA-3' (Mitra et al., 1995). The reaction mixture of PCR was performed by using $1 \mathrm{x}$ Taq pol $25 \mu \mathrm{l}$ of master mix (Axygen Biosciences, CA, USA).

To digest this fragment, a protocol of RFLP with restriction enzyme Mspl was used to recognize the particular site of $\mathrm{C} \downarrow \mathrm{CGG}$. The PCR product of $\mathrm{GH}$ gene was digested at $37{ }^{\circ} \mathrm{C}$ for 3 hours by Mspl enzyme. Reaction consisted of 2 $\mu \mathrm{L}$ Buffer V2 10X, $7.5 \mu \mathrm{L} \mathrm{H}_{2} \mathrm{O}, 0.5 \mu \mathrm{L}$ Enzyme Mspl $(20 \mathrm{U} / \mu \mathrm{L})$, and $10 \mu \mathrm{L}$ PCR product. PCR protocols to amplify the fragment were by the initial denaturation temperature step at $94^{\circ} \mathrm{C}$ for 5 min for 1 cycle followed by 35 cycles of denaturation at $94^{\circ} \mathrm{C}$ for $30 \mathrm{sec}$, annealing at $60^{\circ} \mathrm{C}$ for $30 \mathrm{sec}$, elongation at $72^{\circ} \mathrm{C}$ for $30 \mathrm{~s}$ and a final extension at $72^{\circ} \mathrm{C}$ for $1 \mathrm{~min}$. (Dybus, 2002). Following the end of PCR and RFLP process, the products were then subsequently electrophorated using $1.2 \%$ agarose gel to identify polymorphism of allele based on the length of the band as presented at Figure 1.

PCR-RFLP data were analyzed by allele frequency (Nei, 1987). The allele frequency was calculated by the methods as follows:

$$
\mathrm{x}_{\mathrm{i}}=\left[\left(2 \mathrm{n}_{\mathrm{ii}}+\sum \mathrm{n}_{\mathrm{ij}}\right) / 2 \mathrm{~N}\right]
$$

Where,

$\mathrm{x}_{1}=$ the $M s p 1^{+}$allele frequency,

$\mathrm{n}_{\mathrm{ii}}=$ the number of cattle with the genotype of $\mathrm{Msp1}^{+/+}$,

$\mathrm{n}_{\mathrm{ij}}=$ the number of cattle with the genotype of $\mathrm{Msp}^{+/,}$,
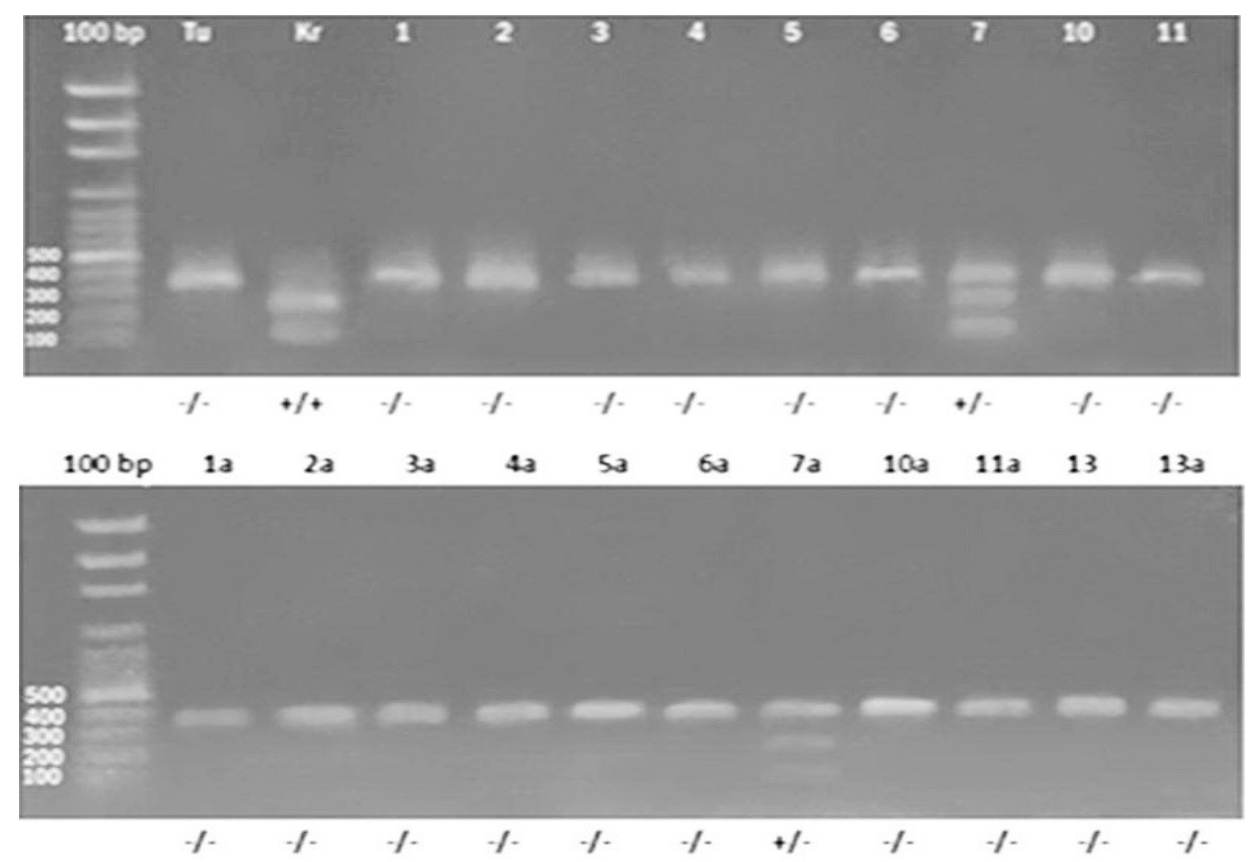

Figure 1. Genotyping Results of Msp1 Enzyme Restriction in GH Locus Detected by Agarose Gel Electrophoresis $(\mathrm{Tu}=$ Ongole bull called Tunggul; $\mathrm{Kr}=$ Ongole bull called Krista, source of sperm for Artificial Insemination (AI); 1 - 11 = samples of cows mated by AI; 1a-13a = samples of progenies produced by AI method using Tu sperms) 
$\mathrm{N}=$ the total number of cattle tested.

DNA extraction and genotyping for $\mathrm{GH}$ and allele identification were done using the protocols in DNA Laboratory (Sulandari and Zein, 2003; Paputungan et al., 2012) showing the indentified alleles presented in Table 1.

DNA extraction and genotyping for $\mathrm{GH}$ and allele identification were done using the protocols in DNA Laboratory as described by (Sulandari and Zein, 2003; Paputungan et al., 2012) showing the indentified alleles and genotypes of the animals as presented in Table 1. The average of two homozygous phenotypes $\left(\mathrm{P}_{11}\right.$ and $\mathrm{P}_{22}$ ), denoted by $m$, was calculated using formula (Van Vleck et al., 1987) as follows:

$m=1 / 2\left(\mathrm{P}_{11}+\mathrm{P}_{22}\right)$

The genotypic values for each genotype of the cows in this study were calculated with the formula according to Van Vleck et al. (1987) as follows:

Genotypic value of the $\mathrm{P}_{11}(\mathrm{a})=\mathrm{P}_{11}-m \ldots$ (2)

Genotypic value of the $\mathrm{P}_{12}(\mathrm{~d})=\mathrm{P}_{12}-m \ldots$ (3)

Genotypic value of the $\mathrm{P}_{22}(-\mathrm{a})=\mathrm{P}_{22}-m$.. (4)

Because $m$ was defined as the phenotypic mean for both homozygous genotypes of 405.03 $\mathrm{kg}$ (using formula 1), the genotypic values of each animal genotype were found for live weight as follows: GH-Mspl ${ }^{+/+}$(a) was $0.30 \mathrm{~kg}$ (using formula 2), $\mathrm{GH}-\mathrm{Mspl}^{+-}$(d) was $93.04 \mathrm{~kg}$ (using formula 3), and GH-Msp1- (- a) was - $0.30 \mathrm{~kg}$ (using formula 4). In addition, the phenotypic mean $(\mathrm{m})$ for both homozygous genotypes of chest girth was $179.045 \mathrm{~cm}$ (using formula 1), the genotypic values were found as follows: $G H-$ $\mathrm{Mspl}^{+/+}$(a) was $3.30 \mathrm{~cm}$ (using formula 2), $\mathrm{GH}$ $\mathrm{Msp1}^{+/-}$(d) was $9.45 \mathrm{~cm}$ (using formula 3), and $G H-M_{s p 1^{-/}}(-$a) was $-3.30 \mathrm{~cm}$ (using formula 4). In the same case, the phenotypic mean $(\mathrm{m})$ for both homozygous genotypes of body length was
Table 1. Band of the Fragment after Mspl Enzyme Restriction

\begin{tabular}{ccc}
\hline $\begin{array}{c}\text { Length of } \\
\text { DNA Band } \\
\text { (bp) }\end{array}$ & Identified Allele & Genotype \\
\hline 224 & Normal allel $\left(M s p 1^{+}\right)^{*}$ & $M s p 1^{+/+}$ \\
103 & & \\
327 & $M s p 1^{+}$and $\mathrm{Msp1}^{-}$ & $M s p 1^{+/-}$ \\
224 & & \\
103 & & \\
\hline 323 & Mutant allel $\left(M s p 1^{-}\right)^{* *}$ & $M s p 1^{-/-}$ \\
\hline
\end{tabular}

*Cut by Msp1 enzyme; **Uncut by Msp1 enzyme

$137.54 \mathrm{~cm}$ (using formula 1), the genotypic values were found as follows: GH-Msp1 $1^{+/+}$(a) was 3.88 $\mathrm{cm}$ (using formula 2), GH-Msp ${ }^{+/-}$(d) was 8.17 $\mathrm{cm}$ (using formula 3), and GH-Msp $1^{-/}$(- a) was $3.88 \mathrm{~cm}$ (using formula 4). These genotypic values were valuable in contribution for all phenotypic and genotypic parameters including population.

For a population in Hardy-Weinberg equilibrium, the phenotypic population mean $(\mu)$ was defined (Van Vleck et al., 1987):

$$
\mu=p^{2} \mathrm{P}_{11}+2 p q \mathrm{P}_{12}+\mathrm{q}^{2} \mathrm{P}_{22}
$$

An alternative computing formula for obtaining the mean is based on substituting $m+$ genotypic value for each phenotype. For a population in equilibrium, the mean is computed using formula (Van Vleck et al., 1987) as follows: $\mu=p^{2}(m+a)+2 p q(m+d)+q^{2}(m-a)$

Table 2. Average of Live Weight and Genotypic Value for Each Genotype GH Restriction Enzyme Mspl in Ongole Grade Cows

\begin{tabular}{|c|c|c|c|c|c|c|c|c|}
\hline \multirow{2}{*}{$\begin{array}{l}\text { Genotype of } \\
\text { Cows }\end{array}$} & \multirow{2}{*}{$\mathrm{n}$} & \multirow{2}{*}{ GF } & \multicolumn{3}{|c|}{ Average of Phenotype } & \multicolumn{3}{|c|}{ Genotypic Value $\left(\mathrm{V}_{\mathrm{ij}}\right)$} \\
\hline & & & LW, kg & $\mathrm{CG}, \mathrm{cm}$ & $\mathrm{BL}, \mathrm{cm}$ & LW, kg & $\mathrm{CG}, \mathrm{cm}$ & $\mathrm{BL}, \mathrm{cm}$ \\
\hline GH-Msp $1^{+/+}$ & 8 & $p^{2}$ & $\mathrm{P}_{11}=405.33$ & $P_{11}=166.75$ & $P_{11}=141.41$ & $\mathrm{a}=0.30$ & $-\mathrm{a}=-3.30$ & $\mathrm{a}=3.88$ \\
\hline$G H-M s p 1^{+/-}$ & 14 & $2 \mathrm{pq}$ & $\mathrm{P}_{12}=498.07$ & $\mathrm{P}_{12}=179.50$ & $\mathrm{P}_{12}=145.71$ & $d=93.04$ & $d=9.45$ & $d=8.17$ \\
\hline GH-Msp $1^{-/-}$ & 15 & $q^{2}$ & $\mathrm{P}_{22}=404.73$ & $\mathrm{P}_{22}=173.34$ & $\mathrm{P}_{22}=133.66$ & $-\mathrm{a}=-0.30$ & $\mathrm{a}=3.30$ & $-\mathrm{a}=-3.88$ \\
\hline
\end{tabular}

$\mathrm{n}=$ number of cows; $\mathrm{GF}=$ Genotype frequency; $\mathrm{LW}=$ Live weight; $\mathrm{CG}=$ Chest girth; $\mathrm{BL}=$ Body length 


$$
=m\left(\mathrm{p}^{2}+2 \mathrm{pq}+\mathrm{q}^{2}\right)+\mathrm{a}\left(\mathrm{p}^{2}-\mathrm{q}^{2}\right)+2 \mathrm{pqd}
$$

Because $p^{2}+2 p q+q^{2}=1$, and $\left(p^{2}-q^{2}\right)=(p$ $+q)(p-q)=(p-q)$, the mean is computed using formula (Van Vleck et al., 1987) as follows:

$\mu=m+[\mathrm{a}(\mathrm{p}-\mathrm{q})+2 \mathrm{pqd}]$

Heritability is an extremely important population parameter that is used both for the estimation of breeding values for quantitative characteristics and for predicting the response expected from various selection schemes. The phenotypic variance $\left(\sigma_{\mathrm{p}}^{2}\right)$ was calculated using formula (Van Vleck et al., 1987):

$$
\sigma_{\mathrm{p}}^{2}=2 \mathrm{pq} \alpha^{2}+(2 \mathrm{pqd})^{2}
$$

The Greek alpha $(\alpha)$ is used to represent specifically a part formula of $\{a+d(q-p)]$ as found in Van Vleck et al. (1987). Thus, the Greek alpha $(\alpha)$ is defined as:

$\alpha=[a+d(q-p)]$

Standard error of phenotypic variance is obtained from $\sqrt{\sigma_{p}^{2}}$

The additive genetic variance $\left(\sigma_{\mathrm{A}}^{2}\right.$ for a single locus, is calculated using formula (Van Vleck et al., 1987):

$$
\sigma_{\mathrm{A}}^{2}=2 \mathrm{pq} \alpha^{2}
$$

Heritability in the narrow sense $\left(h^{2}\right)$ is defined as the ratio of the additive genetic variance to the phenotypic variance (Van Vleck et al., 1987):

$$
\begin{aligned}
& h^{2}=\sigma_{A}^{2} / \sigma_{P}^{2} \\
& \text { RESULTS AND DISCUSSION }
\end{aligned}
$$

The growth hormone $(\mathrm{GH})$ genotypes using restricted enzyme of $M s p 1$ for 37 cows were applied in this study. The PCR-RFLP data were used in establishing the observed homozygous $\mathrm{Mspl}^{+/+}$genotype, heterozygous $\mathrm{Mspl}^{+/-}$genotype and homozygous $\mathrm{Mspl}^{-/}$genotype as showed in Table 1 . The 37 genotyped parental cows showed that 15 cows were detected to have homozygous genotype of the $\mathrm{Mspl}^{-/}$in GH locus, 14 cows were detected to have heterozygous genotype of the $\mathrm{Msp}^{+/-}$in GH locus, and 8 cows were detected to have homozygous genotype of the $\mathrm{Mspl}^{+/+}$in GH locus.

The number of cows and the average of the phenotypic values of cow population for this study are presented in Table 2. Live weight was affected by the genotype at the locus of GH-Mspl. The animal population was considered at the equilibrium with existing of gene frequency and phenotypic measurements as shown in Table 2. The $\mathrm{GH}-\mathrm{Mspl}^{+}$represented allele affecting animal live weight. Cow genotype represented each animal phenotype performance measured in the $\mathrm{kg}$ unit of cow body weight and $\mathrm{cm}$ unit of cow chest girth and body length. Genotype value was defined as deviation of phenotype from the mean of both homozygous phenotypes of $\mathrm{P}_{11}$ and $\mathrm{P}_{22}$ (shown at formula 1).

Using 37 samples of the cows in this study, the allele frequency $G H-M s p I^{+}$(p) were $24 / 74=$ 0.32 . Because $\mathrm{p}=0.32$, the allele frequency of GH-MspI (q) $=0.68$. Therefore, the population mean of the cows $(\mu)$ (using formula 5) were $445.41 \mathrm{~kg}$. Those values indicated that live weight mean of the cow population in this study would be about $445.41 \mathrm{~kg}$. The estimation average population of animal chest girth (using formula 5) in this study were $175.35 \mathrm{~cm}$. Morever, the estimation average population of animal body length (using formula 5) in this study were 139.70 $\mathrm{cm}$.

Using 37 samples of the cows in this study, the allele frequency $G H-M s p 1^{+}$(p) were 24/74 = 0.32 . Because $\mathrm{p}=0.32$, the allele frequency of GH-MspI $I^{-}$(q) $=0.68$. Thus, the genotype frequency of the animals in the population would be 0.10 for genotype $G H-M s p 1^{+/+}, 0.44$ for genotype of $\mathrm{GH}-\mathrm{Mspl}^{+/}$, and 0.46 for genotype of GH-Msp $1^{-1}$. Variation of observation for mean could be calculated in term of variance. In this study, the variance is denoted $\left(\sigma_{\mathrm{p}}^{2}\right)$ to represent phenotype variance. Using formula (7), the value of phenotype variance $\left(\sigma_{\mathrm{p}}^{2}\right)$ in this study were 2109.34. Thus, using formula (8), the standard error value of phenotype $\left(\sigma_{\mathrm{p}}^{2}\right)$ in this study were $45.93 \mathrm{~kg}$. The estimation average population of animal live weight (using formula 5 and 8 ) in this study were $445.41 \pm 45.95 \mathrm{~kg}$.

Using formula (9), the additive genetic variance $\left(\sigma_{\mathrm{A}}^{2}\right)$ in a single locus was 496.90. Therefore, the heritability of cow live weight as calculated using formula (10) in this study was 0.24 . This heritability value of cow live weight would be categorized as moderate value (Van Vleck et al., 1987). For breeding program, the heritability $\left(\mathrm{h}^{2}\right)$ in narrow sense using the additive genetic variance $\left(\sigma_{\mathrm{A}}^{2}\right)$ was applicably more accurate in the improvement prediction for animal economically traits, including animal live weight, due to the representation and expression of the quantitative gene action involved. The accuracy of this heritability value of 0.24 based on individual records was about 55 percents (Legates and Warwick, 1990).

In chest girth measurement, the value of 
phenotype variance $\left(\sigma_{\mathrm{p}}^{2}\right)$ in this study was 16.92 $\mathrm{cm}$ (using formula 7). Thus, using formula (8), the standard error value of phenotype $\left(\sigma_{p}^{2}\right)$ in this study was $4.11 \mathrm{~cm}$. The eatimation average population of animal chest girth (using formula 5) in this study were $175.35 \pm 4.11 \mathrm{~cm}$. Using formula (9), the additive genetic variance $\left(\sigma_{\mathrm{A}}^{2}\right)$ in a single locus was 0.0045 . Therefore, the heritability of cow chest girth as calculated using formula (10) in this study was 0.003. This heritability value of cow chest girth would be categorized as low value (Van Vleck et al., 1987). For breeding program, the heritability $\left(\mathrm{h}^{2}\right)$ in narrow sense using the additive genetic variance was not applicably accurate in the improvement prediction for animal economically traits in term of animal chest girth, due to the expression of the quantitative gene action involved. The heritability value of less than 0.15 was categorized as low inheritance of the trait (Van Vleck et al., 1987).

In body length measurement, the value of phenotype variance $\left(\sigma_{\mathrm{p}}^{2}\right)$ in this study was 32.89 $\mathrm{cm}$ (using formula 7). Thus, using formula (8), the standard error value of phenotype in this study were $5.73 \mathrm{~cm}$. The eatimation average populations of animal body length (using formula 5) in this study were $139.70 \pm 5.73 \mathrm{~cm}$. Using formula (9), the additive genetic variance $\left(\sigma_{A}^{2}\right)$ in a single locus was 20.24. Therefore, the heritability of cow body length as calculated using formula (10) in this study was 0.41 . This heritability value of cow body length would be categorized as high value (Van Vleck et al., 1987). For breeding program, the heritability $\left(\mathrm{h}^{2}\right)$ in narrow sense using the additive genetic variance $\left(\sigma_{A}^{2}\right)$ was applicably more accurate in the improvement prediction for animal economically traits in term of animal body length, due to also the expression of the quantitative gene action involved. The heritability value of more than 0.30 was categorized as high inheritance of the trait (Van Vleck et al., 1987).

\section{CONCLUSION}

The phenotypic estimation average of Ongole grade cattle population of live weight, chest girth and body length were $445.41 \pm 45.95$ $\mathrm{kg}, 175.35 \pm 4.11 \mathrm{~cm}$, and $139.70 \pm 5.73 \mathrm{~cm}$, respectively. The genotypic performance in term of heritability values of animal live weight, chest girth and body length were $0.24,0.003$, and 0.41 , respectively. These heritability values of animal live weight and body length would be categorized as moderate to high genotypic performance values, while the heritability of animal chest girth was included in low heritability standard of the animal economical trait performance.

\section{ACKNOWLEDGMENT}

The financial support of the Ministry of Education and Culture, Republic of Indonesia through their Research Finance Program is gratefully acknowledged. The authors also acknowledge J. Kuhu and his farmer group members at Tumaratas village, district of West Langowan, under development of the artificial insemination service center of Minahasa regency, North Sulawesi province for their assistance in animal data collection.

\section{REFERENCES}

Allan, M.F., R.M. Thallman, R.A. Cushman, S.E. Echternkamp, S.N. White and L.A. Kuehn. 2007. Association of a single nucleotide polymophisme in SPP1 with growth traits and twinning in a cattle population selected for twinning rate. J. Anim. Sci. 85(2):341347

Ayuk, J. and M.C. Sheppard. 2006. Growth hormone and its disorder. Postgrad. Med. J. 82(63):24-30.

Beauchemin, V.R., M.G. Thomas, D.E. Franke and G.A. Silver. 2006. Evolution of DNA polymorphisms involving growth hormone relative to growth and carcass characteristics in Brahman steers. Genet. Mol. Res. 5(3):438-447

Dybus, A. 2002. Associations of growth hormone (GH) and prolactin (PRL) genes polymorphism with milk production traits in Polish Black-and-White cattle. Anim. Sci. Papers Reports. 20(4):203-212

Gordon, D.F., D.P. Quick, C.R. Erwin, J.E. Donelson and R.A. Maurer. 1983. Nucleotide sequence of the bovine growth hormone chromosomal gene. Mol. Cell. Endocrinol. 33(1):81-95

Jain, J. and P. Prabhakaran. 1992. Genetics of Populations. South Asian Publishers PVT. LTD. New Delhi.

Jakaria, D., D. Duryadi, R.R. Noor, B. Tappa and H. Martojo. 2007. Evaluasi keragaman genetik hormon pertumbuhan (GH) pada sapi pesisir Sumatera Barat menggunakan penciri PCR-RFLP. Med. Pet. 30(1):1-10 
Jakaria, R.R. Noor, H. Martojo, D. Duryadi and B. Tappa. 2009. Identification of growth hormone (Gh) gene MspI and AluI loci polymorphism in beef cattle. Faculty of Animal Science, Bogor Agricultural University. The $1^{\text {st }}$ International Seminar on Animal Industry 2009. p.42-47

Legates, J.E., and E.J. Warwick. 1990. Breeding and Improvement of Farm Animals. McGraw-Hill Publishing Company. New York.

Maylinda, S. 2011. Genetic polymorphism of growth hormone locus and its association with body weight in Grati dairy cows. Inter. J. Biotech. Mol. Biol. Res. 2(7):117-120.

Mitra, A., P. Sciilee, C.R. Balakrisiinan and F. Pirciiner. 1995. Polymorphisms at growth hormone and prolactine loci in Indian cattle and buffalo. J. Anim. Breed. and Genet. 12:71-74

Nei, M. 1987. Genetic distance between populations. Amer. Nat. 106:283-292.

Ozkaya, S. and Y. Bozkurt. 2008. The relationships of parameters of body measures and body weight by using digital image analysis in pre-slaughter cattle. Arch Tiers. 51:120-128

Paputungan, U., M. Makarechian and M.F. Liu.
2000. Effects of sire birth weight on calving difficulty and maternal performance of their female progeny. Asian-Aust. J. Anim. Sci. 13(13):729-732

Paputungan, U, L. Hakim, G. Ciptadi and H.F.N. Lapian. 2012. The allele frequencies of growth hormone gene on the parental and progeny of Ongole-crossbred cattle population in the North Sulawesi of Indonesia using PCR-RFLP. J. Evol. Biol. Res. 4(3):52-58.

Sodhi, M., M. Mukesh, B. Prakash, B.P. Misha, R.C. Sobti and K.P. Singh. 2007. Msp1 allelic pattern of bovine gene in Indian zebu cattle (Bos indicus) breeds. Biochem. Genet. 45(1-2):145-153

Sutarno, A., Junaidi, and B. Tappa. 2005. Polimorfisme MspI pada lokus 2 gen hormon pertumbuhan sapi PO dan pengaruhnya terhadap capaian berat badan harian. Biodiversitas. 6 (2):77-81

Sulandari, S. and M.S.A. Zein. 2003. Protocols in DNA Laboratory, Center of Biology Research, The Indonesian Institute of Sciences. Pp.23-45

Van Vleck, L.D., E.J. Pollak and E.A.B. Oltnacu. 1987. Genetics for the Animal Science. W.H. Freeman and Company, New York. 